\title{
繰返し水平力を受ける $\mathrm{RC}$ 柱及び $\mathrm{SRC}$ 柱の性能評価 EVALUATION ON PERFORMANCE OF RC COLUMNS AND SRC COLUMNS SUBJECTED TO REPEATED HORIZONTAL FORCE
}

\author{
内田保博*1, 古城康彦*2, 坊地彰人*3, 三谷 勲*4, 有馬冬樹*5 \\ Yasuhiro UCHIDA, Yasuhiko KOJO, Akito BOCHI, \\ Isao MITANI and Fuyuki ARIMA
}

\begin{abstract}
Since the strong horizontal force occurred in earthquake often causes cumulative damage such as the strength deterioration and the accumulation of deformation in structures and their members, the prediction of cumulative damage is needed in an aseismic design of structures. In this study, the critical axial force for convergence-axial displacement curves of RC and SRC beam-columns are proposed as a characteristic curve for repeated loading in order to predict the cumulative damage. Tests and analyses of RC and SRC beam-columns were carried out and it was found that the cumulative damage could be evaluated by the curves very well.
\end{abstract}

Keywords: Reinforced concrete, Steel reinforced concrete, Column, Bending failure, Shear failure, Axial force 鉄筋コンクリート、鉄骨鉄筋コンクリート、柱、曲げ破壊、せん断破壊、軸力

\section{1. 序}

大地震時における構造物の終局的な耐震安全性を保証するために は、構造部材の繰返し載荷時の挙動を把握するとともに、繰返し力 に対する抵抗性能の評洒法を確立しておく必要がある。1995年に発 生した兵庫県南部地震では多くの構造物に損諹が見られ、耐力低下 や変形の累積が生じたと思われる。設計の段階で地震の規模に対応 してこれらの被害を想定しておくことが望まれるが、現在のところ 累積損傷制御の観点から損傷を予測する方法については、十分に調 べられていない。

構造物に繰返し変動荷重が作用して塑性化が生じるとき、その挙 動は塑性解析の分野ではシェイクダウン、交番塑性及び漸増崩壊に 分類されることが示されている。特に繰返し回数が増加してあるサ イクル以降は弹性挙動をするシェイクダウンについては、多くの研 究者により調べられてきた㓯活1)。一方定鉛直力と繰返し曲げを受 ける鋼柱や鋼骨組の変形累積の定式化が、塑性解析之は別のアプ ローチにより、部材の荷重一変形関係における履歷を追うことによ り行われた 2〉 》。加藤・秋山は繰返し加力下の構造物や部材の荷重 一変形関係を、一方向加力下での荷重一変形から得るためのモデル
を提案している ${ }^{8)}$ 。定軸力及び渐增の定変位振幅繰返し水平力を受 ける柱に非対称変形が生じる変位振幅の限界や非対称変形が定常化 する限界は上谷ら ${ }^{93 、 10)}$ により見い出され、各々対称限界及び定常 状態限界之呼ばれている。繰返し加力時には、1 方向単調加力時に は見られない特有の現象及び挙動が存在する。羽倉 ${ }^{11}$ は繰返し曲げ や繰返し水平力を受ける柱の解析により、漸增の塑性変形が生じる 限界の荷重や変形として各々定義される安定限界荷重や安定限界変 形が存在することを示している。また宇田川、高梨ら ${ }^{12)}$ は、定常限 界变位振幅を超えて繰返し载荷されると履歷曲線が非定常になり耐 力低下が生じることを報告している。松井ら ${ }^{133}$ は定变位振幅や漸增 振幅繰返し水平力を受けるSRC柱の解析や実験を行い、変形累積が 収束し耐力低下が進行しない限界時の安定限界軸力について調へて おり、平石 ${ }^{14)}$ は繰返し載荷を受けるRC柱に、引張り鉄筋の伸び の上限点としての安定限界及び安定した履歴挙動を示す変形の限界 が存在することを実験及ご解析により明らかにしている。また衣笠

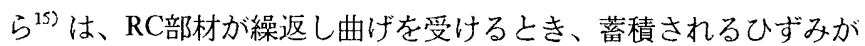
限界に達すると破壊が生じることや、耐力低下が生じるときに軸ひ ずみが増加から減少に転し横方向のひずみが急增することを示して

*概要については，文献20)～27)にて発表している。

*1 鹿児島大学:工学部建築学科 助教授. 工博

*2 西松建設( $($ 怢) 工修

*3 安藤建設(侏) 工修

*4 神戸大学工学部建設学科 教授・工博

*5 大和八ウス工業株) 工修

Assoc. Prof., Dept. of Architecture, Faculty of Eng., Kagoshima University, Dr. Eng. Nishimatu Construction Co., M. Eng.

Ando Construction Co., M. Eng.

Prof., Dept. of Construction, Faculty of Eng., Kobe University, Dr. Eng. Daiwa House Industry Co., M. Eng. 
いる。

本研究では、繰返し力を受ける構造物の変形累積挙動に鉛直力の 大きさに応じて収束・発散挙動が存在し、これが構造物の耐力低下 挙動等の累積損傷举動に関連していることに着目して、繰返し加力 時の累積損傷に対する抵抗性能を表わす特性曲線を得る方法を提示 する。この特性曲線は、柱が繰返し水平力を受けるとき、各サイク ルにおける最大軸咨位がある值に収束するときの定軸力と収束時の 軸変位の関係を連続的にプロットした曲線であり、本研究ではこれ を収束限界軸力曲線と呼んでいる。そしてさらに、鉄筋コンクリー 卜 $(\mathrm{RC})$ 柱及び鉄骨鉄筋コンクリート (SRC) 柱の収束限界軸力曲線 を実験及び解析により求めて、曲線による累積損傷予測の妥当性に ついて検討する。

本研究の特色は、軸力と繰返し水平力を受ける柱に耐力低下や軸 変形等の損傷が生じるとき、収束限界軸力曲線と呼んでいる特性曲 線により損慯を予湘することにある。すなわちこの特性曲線によ り、定軸力や変動軸力の下で繰返し水平力を受ける柱の損傷の収 束・発散挙動や損傷の累積の程度を、作用する軸力と収束限界軸力 曲線の関係から定性的に予測できるか否かについて調べることにあ る。上記の安定限界軸力 ${ }^{13}$ 它安定限界荷重 ${ }^{111}$ は、収束限界軸力曲線の 極限点に相当すると考えられるが、理論解が得られないために数值 計算により安定限界を求めていく一般的なケースでは、安定限界近 傍の力学的挙動が示されないために、これらの安定限界荷重を用い て厳密に安定性を論じることは困難と思われる。

\section{2. 収束限界軸力曲線}

2.1 収束限界軸力曲線の定義

本研究で損傷の累積を予測するために提案された収束限界軸力 曲線は、以下のように定義される。

図1は軸力P $\mathrm{P}$ 図 2 に示守定变位振幅的の絽返し水平力Hを受ける片 持ちRC柱及びSRC柱のモデルである。収束限界軸力とは、繰返し水 平力を受ける柱の軸変位の初期値が基準点より大きくある值（図3に おいてaで表示）上り小さいとき、各サイクルにおいて累積する軸変 位の最大值がある值に収束する限界の軸力P $P_{\alpha}$ であり（図3）、収束限 界軸力と収束時の軸変位の最大值との関係を連続的にプロットした 曲線を收束限界軸力曲線と呼ぶことにする。ここに基準点(Origin)と は、原点又は収束限界軸力曲線の反転点であり、基準点として原点 をとる場合は原点から軸力が載荷されるときであり、原点より上の 軸力に対して軸変位は正側に累積する。また反転点とは、軸力が変 化して軸変位の累積方向が逆転するときの基準点であり、反転点よ り小さな軸力の下では軸変位の累積方向は逆転して図3に示すように 負側に累積する。变動軸力を受ける柱の累皘損傷を予測するため に、軸力の変動に応じて反転点後の収束限界軸力曲線を用いること ができる。以後、軸力-軸変位関係において、引張軸力および軸変位 の伸びの符号を正とする。な打収束限界軸力曲線は、ある定軸力の 下で定変位振幅の繰返し水平力を与えて収束限界軸力と軸変位を求 めた後、順次軸力を增加させることにより得ることができる。しか しこの軸力を增加させる方法では、曲線の極限点を超えた後曲線を 得ることが困難なので、次の $2.2 て ゙$ 示すように収束時の軸変位を順次 増加させる軸变位制御により収束限界軸力曲線を得ることにする。

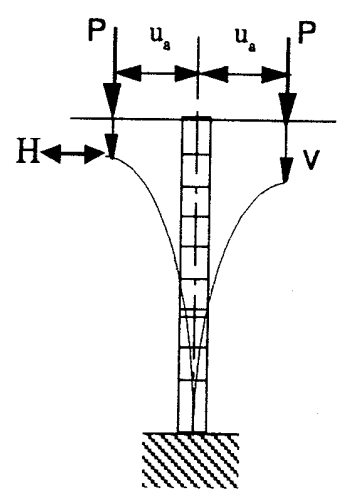

図1 片持柱

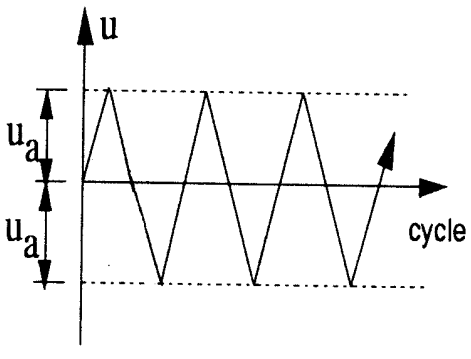

図2 水平変位履歴

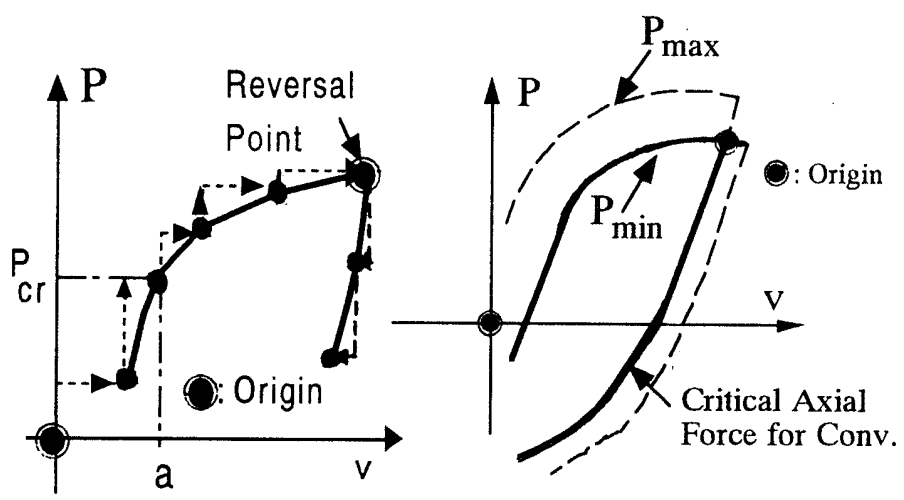

図3 収束限界軸力曲線

図4 収束限界軸力曲線の導出
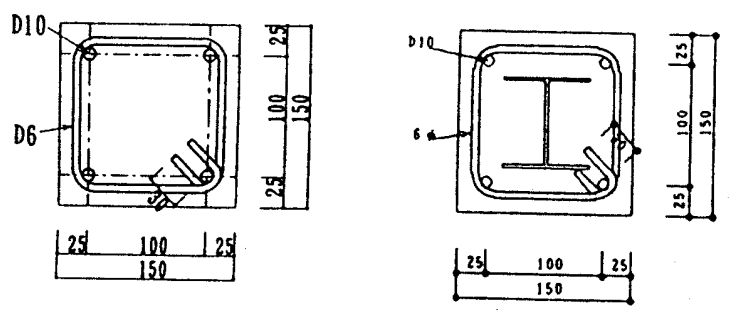

(b) SRC断面 (a) RC断面

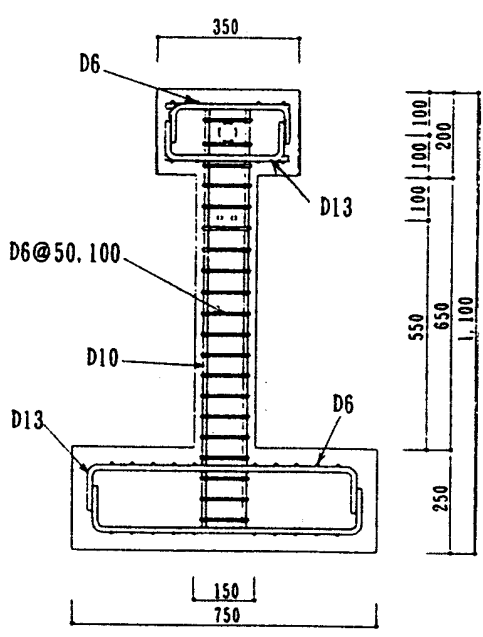

図5 試験体（単位：mm）

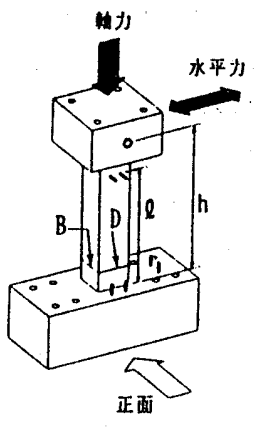




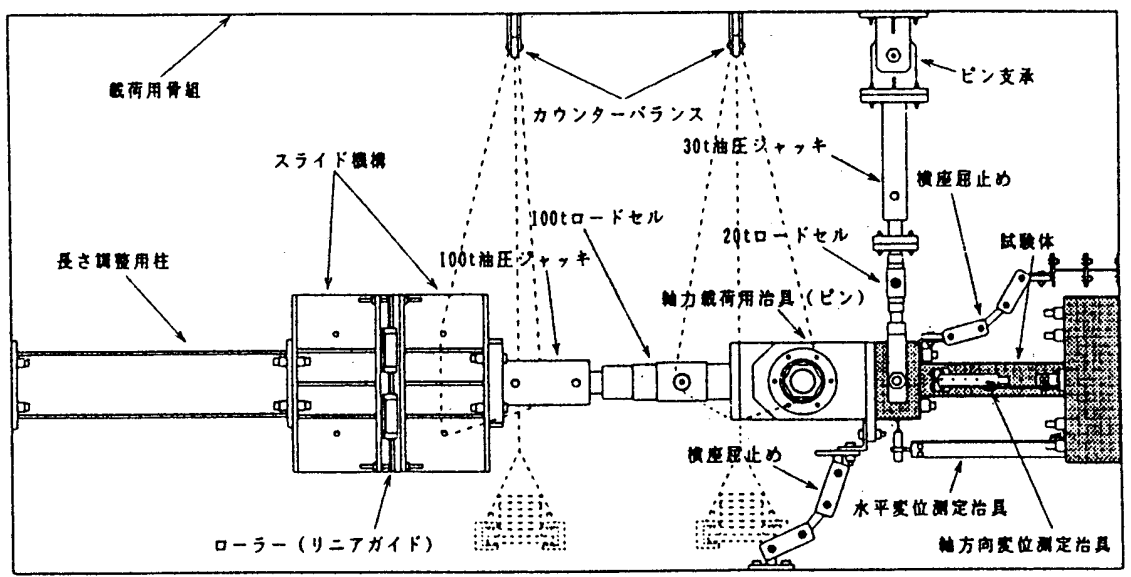

図6 実験装置

2.2 収束限界軸力曲線の導出方法

次に柱の収束限界軸力を得るための手順を以下に記す。

1)収束して定常化した時の柱頭の軸変位の履歴を仮定して与える。

2) 与えられた軸変位の下で繰返し水平力を加える。

3) 2)の加力の過程で軸力が変動するが、定常化したときの変動軸力 の最大值 $\mathrm{P}_{\text {max }}$ と最小軸変位の関係を表す曲線と最小值 $\mathrm{P}_{\text {min }}$ と最大軸 変位の関係の曲線を図4に示す。変形の累積が正側に生じるPの正 側では、変動する軸力の最小值 $\mathrm{P}_{\text {min }}$ (図4）が絶対値の最小値とな り、これが収束限界軸力となる。一方変形累積が負側に進行する 領域では、図4中の変動軸力の最大値 $\mathrm{P}_{\text {max }}$ が収束限界軸力となる。 従って図4中の太線が収束限界軸力曲線になる。

4) 次ステップの収束時軸変位履歷を仮定して2)へ戻る。

なお4)で与える軸変位が増加から減少に転ずれば図4に示すように 反転点が表れる。以後順次軸変位を減少させることにより、反転 点後の収束限界軸力曲線を得ることができる。

上記の計算手順は、文献16）で提案した定理を図1のモデルに適 用することにより得られる次の定理から導かれる。

「図1に示す片持柱が図2の定変位振幅の繰返し水平力と軸変位 増分 $\left\{\Delta \delta_{i}\right\}$ を受けて定常化するとき、軸変位 $\left\{\delta_{i}\right\}$ に対応する 変動軸力の最小值 $\mathrm{P}_{\text {min }}$ (図4) は、収束限界軸力之一致する。 $\left\{\delta_{\mathrm{i}}\right\}$ $+\left\{\Delta \delta_{\mathrm{i}}\right\}$ の最大值は、収束時軸変位の最大值である。」 ただしこの定理は、与えられた $\left\{\delta_{i}\right\}+\left\{\Delta \delta_{i}\right\}$ の下での荷重一 変形関係の履歴経路が、収束限界軸力の下で $\left\{\delta_{\mathrm{i}}\right\}+\left\{\Delta \delta_{\mathrm{i}}\right\}$ の 最大値に変位が収束するときの履歴経路に一致するときにのみ厳 密に成立する。なお繰返し水平力と軸変位増分 $\left\{\Delta \delta_{\mathrm{i}}\right\}$ を与えた とき軸力は一般に一定にならないが、収束限界軸力の下での正し い軸変位增分を与えたときは軸力は一定になる。

\section{3. 軸力と綝返し水平力を受ける RC柱及びSRC柱の実釦}

\section{1 試験体及び材料特性}

図5に実験で用いたRC及びSRC柱試験体の形状及び寸法を示す。 $\mathrm{RC}$ 試験体及びSRC試験体の断面寸法は $150 \mathrm{~mm} \times 150 \mathrm{~mm}$ とし、試験体 数は帯筋間隔 $50 \mathrm{~mm} 5$ 体（せん断補強筋比 ${ }_{\mathrm{w}} \mathrm{p}=0.85 \% 、 \mathrm{RC} 1 \sim \mathrm{RC} 3$ 、 $\mathrm{SRC} 1 、 \mathrm{SRC} 2$ 、曲げ破壊タイプ）、帯筋間隔 $100 \mathrm{~mm} 3$ 体
表1 実験パラメータ

\begin{tabular}{cccccccc}
\hline $\begin{array}{c}\text { Spec. } \\
\text { No. }\end{array}$ & $\begin{array}{c}\mathrm{B} \\
(\mathrm{mm})\end{array}$ & $\begin{array}{c}\mathrm{D} \\
(\mathrm{mm})\end{array}$ & $\begin{array}{c}\ell \\
(\mathrm{mm})\end{array}$ & $\begin{array}{c}\mathrm{h} \\
(\mathrm{mm})\end{array}$ & $\begin{array}{c}\mathrm{F}_{\mathrm{c}} \\
\left(\mathrm{kg} / \mathrm{cm}^{2}\right)\end{array}$ & $\begin{array}{c}\mathrm{wp} \\
(\%)\end{array}$ & $\begin{array}{c}\mathrm{x} \\
(\mathrm{mm})\end{array}$ \\
\hline $\mathrm{RC1}$ & 149.2 & 151.2 & 750.1 & 549.4 & 412 & 0.85 & 50 \\
$\mathrm{RC2}$ & 149.0 & 153.1 & 751.7 & 550.0 & 339 & 0.85 & 50 \\
$\mathrm{RC3}$ & 150.1 & 152.1 & 751.0 & 548.7 & 407 & 0.85 & 50 \\
$\mathrm{RC4}$ & 150.6 & 150.5 & 749.7 & 549.9 & 446 & 0.43 & 100 \\
$\mathrm{RC5}$ & 150.3 & 150.6 & 750.6 & 549.3 & 401 & 0.43 & 100 \\
$\mathrm{RC6}$ & 151.7 & 151.6 & 749.2 & 549.1 & 420 & 0.43 & 100 \\
\hline $\mathrm{SRC1}$ & 148.5 & 150.5 & 750.0 & 550.5 & 388 & 0.85 & 50 \\
$\mathrm{SRC2}$ & 149.0 & 149.8 & 748.3 & 552.5 & 378 & 0.85 & 50 \\
\hline
\end{tabular}

$\mathrm{B}=$ width, $\mathrm{D}=$ depth of cross section

$\ell=$ length to the pin, $\mathrm{h}=$ height of column, $\mathrm{F}_{\mathrm{c}}=$ compression strength of ${ }_{w} p=$ hoop ratio, $x=$ spacing of hoops concrete

表 2 鉄筋及び鉄骨の機械的性質

\begin{tabular}{|c|c|c|c|c|}
\hline \multicolumn{2}{|c|}{ Materials } & $\begin{array}{c}\sigma_{y} \\
\left(\mathrm{t} / \mathrm{cm}^{2}\right)\end{array}$ & \multirow{2}{*}{$\begin{array}{c}\begin{array}{c}\sigma_{u} \\
\left(\mathrm{t} / \mathrm{cm}^{2}\right)\end{array} \\
6.11\end{array}$} & \multirow{2}{*}{$\begin{array}{c}\delta \\
(\%) \\
18.4\end{array}$} \\
\hline \multirow{3}{*}{ Re-Bars } & D-6 & 3.96 & & \\
\hline & D-10 & 3.56 & 5.22 & 20.2 \\
\hline & $\mathrm{D}-13$ & 3.44 & 5.02 & 19.4 \\
\hline \multicolumn{2}{|c|}{ 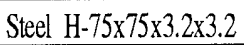 } & 3.73 & 4.6 & 20.6 \\
\hline
\end{tabular}

$\sigma_{y}=$ yield stress, $\sigma_{u}=$ tensile strength $\delta=$ elongation

表3 試験体の破壊形式之加力形式

\begin{tabular}{c|ccc|ccc|cc}
\hline Specimens & RC1 & RC2 & RC3 & RC4 & RC5 & RC6 & SRC1 & SRC2 \\
\hline Failure Type & B & B & B & S & S & S & B & B \\
\hline Loading Type & 3 & 1 & 2 & 2 & 1 & 3 & 1 & 3 \\
\hline
\end{tabular}

B: bending failure, $\mathrm{S}$ : shear failure

1: Test1( loaded with constant axial disp.)

2: Test2( loaded with variable axial disp.)

3: Test3 (loaded with constant axial force) 


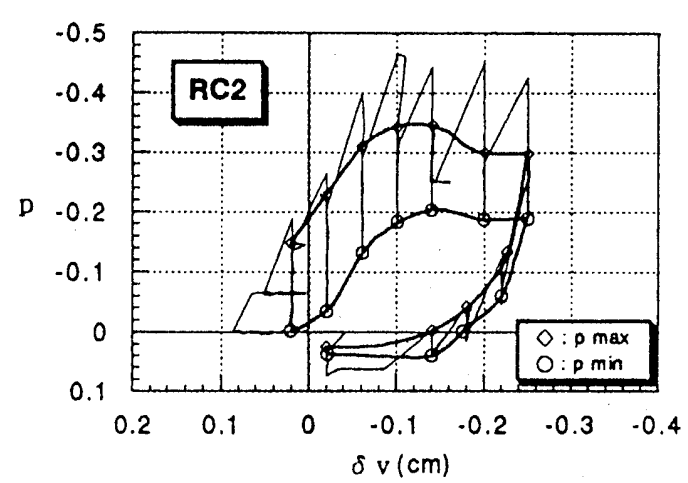

(a) 曲け破壊タイプ

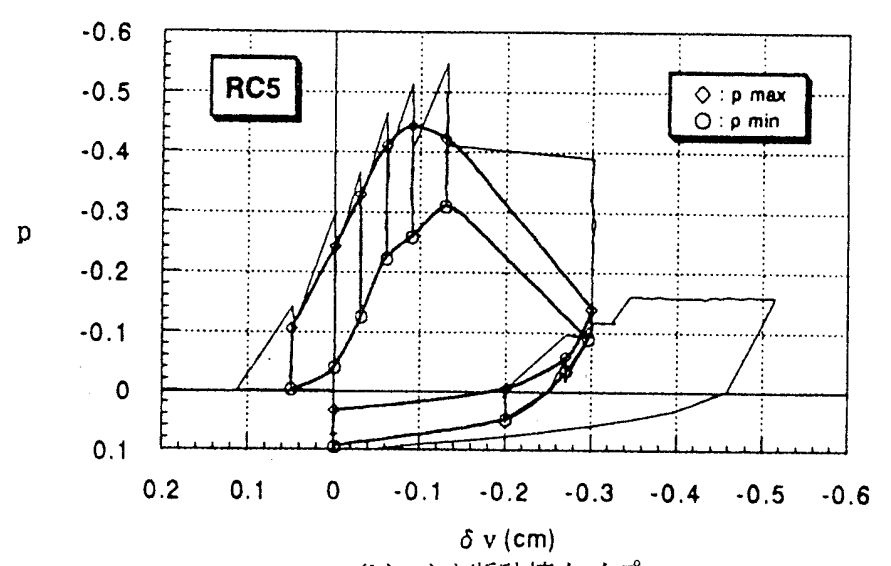

(b) せん断破壊夕イプ

図7 RC柱の軸力一軸変位関係 (加力方法1)

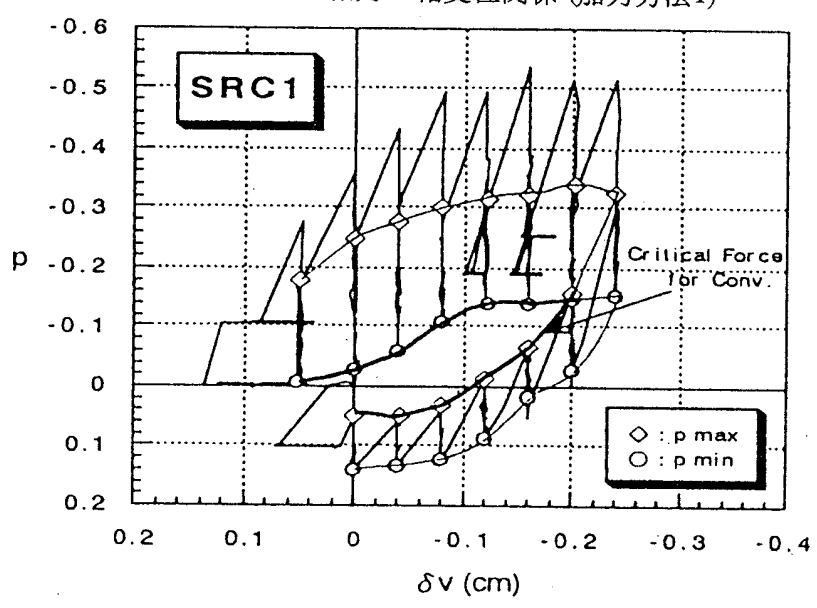

図8 SRC柱の軸力一軸変位関係 (加力方法 1 )

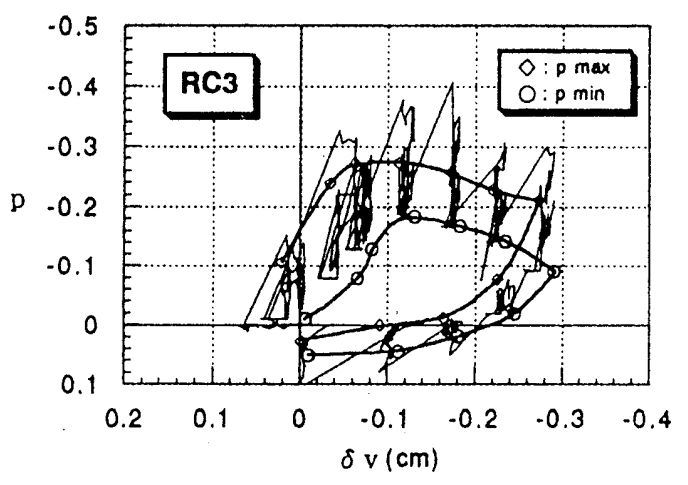

(a) 曲げ破壊タイプ

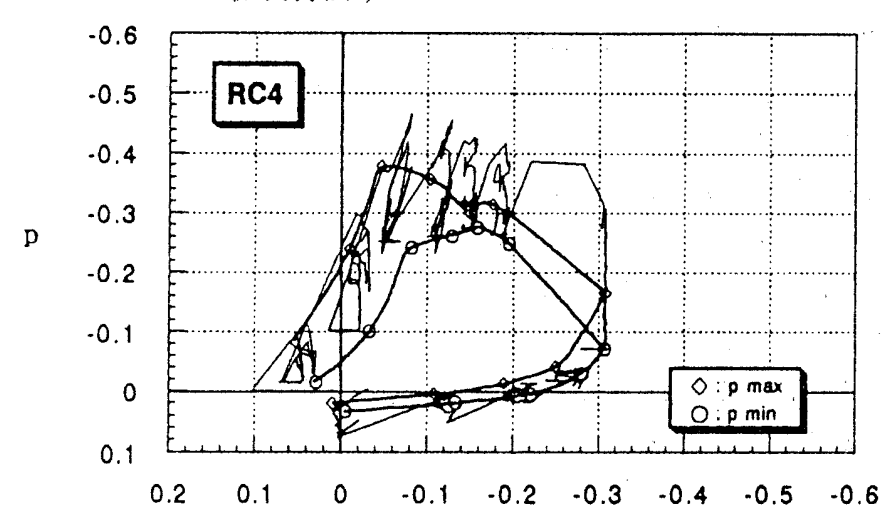

(b) せん断破壊夕イプ

図9 RC柱の軸力ー軸変位関係 (加力方法2)

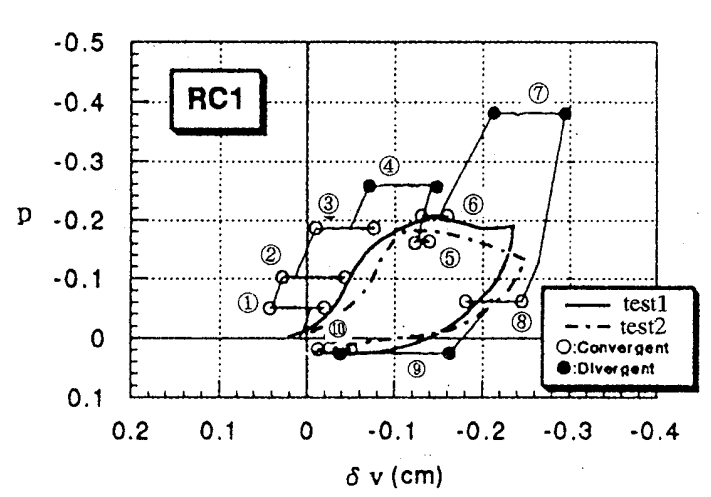

(a) 曲げ破壊夕イプ

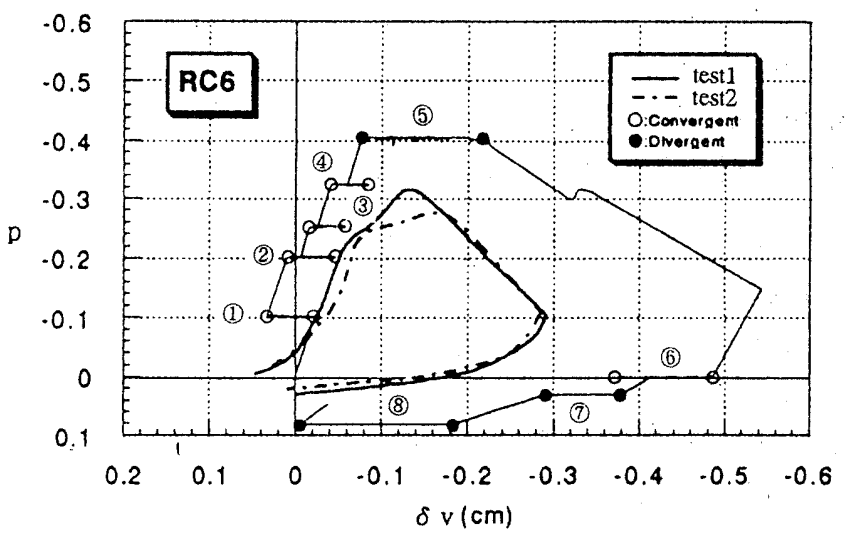

(b) せん断破壊夕イプ

図10 RC柱の収束限界軸力曲線及び一定軸力下での損智の累積 


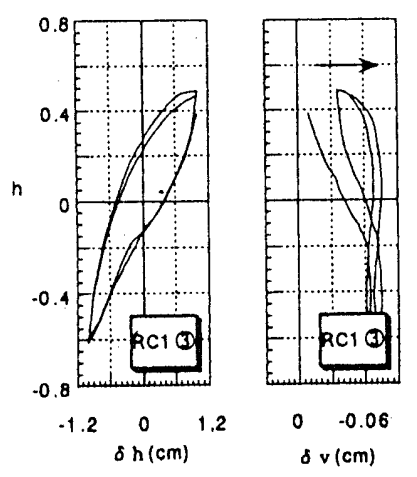

(a) $\mathrm{p}=-0.18$

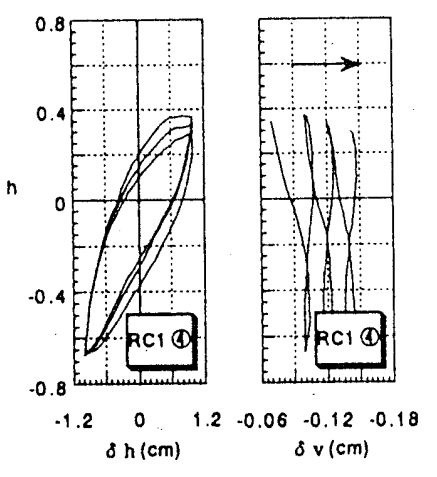

(b) $\mathrm{p}=-0.26$
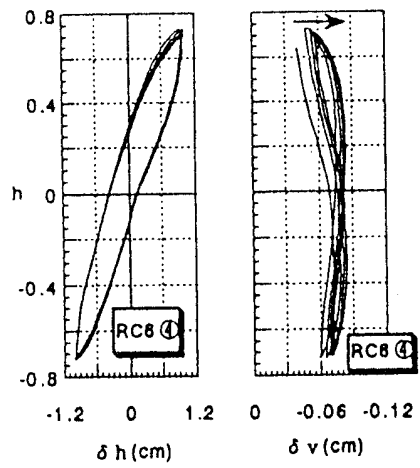

(a) $\mathrm{p}=-0.33$

図12 RC柱の履歴曲線 (せ九断破壊タイプ)

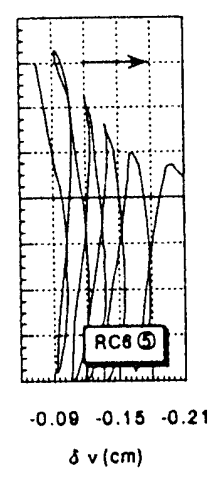

図11 RC柱の履歴曲線 (曲げ破壊夕イプ)

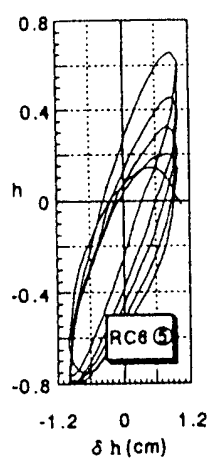

$\delta \mathrm{v}(\mathrm{cm})$

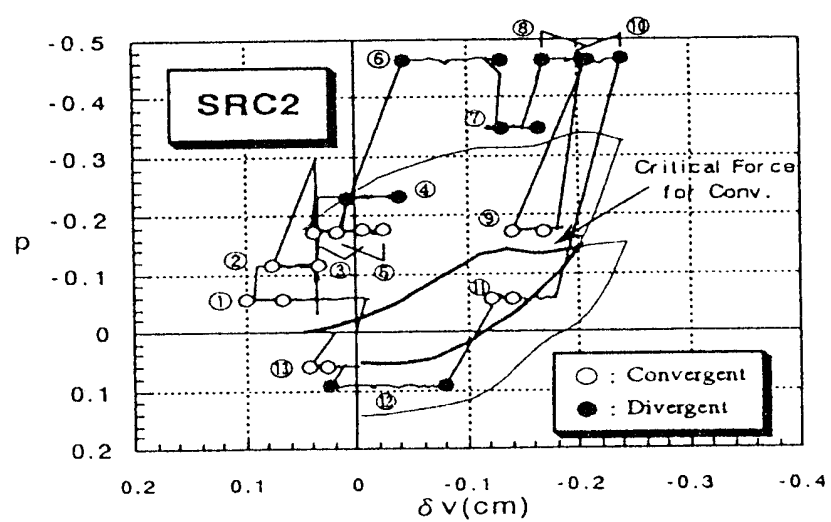

图13SRC柱の軸力一軸変位関係 (加力方法2、3)

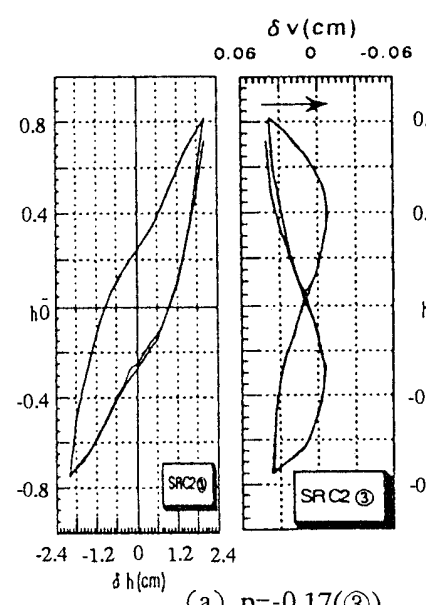

(a) $\mathrm{p}=-0.17($ (3)
$0.06 \begin{gathered}\delta v(\mathrm{~cm}) \\ 0\end{gathered}-0.06$

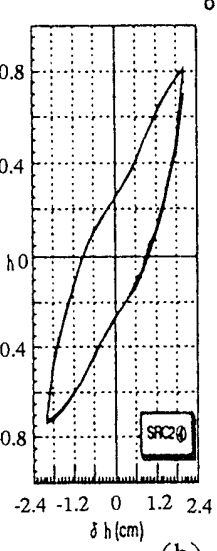

(b) $\mathrm{p}=-0.23$ (4)

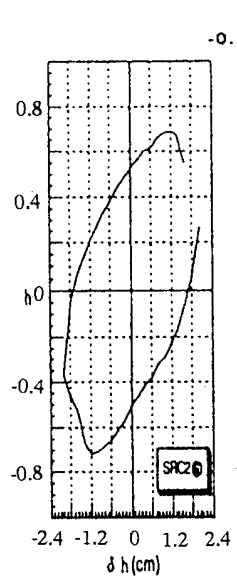

(c) $\mathrm{p}=-0.46(6))$
$0.03 \begin{array}{cc}\delta \vee(\mathrm{cm}) \\ -0.09\end{array}-0.15$

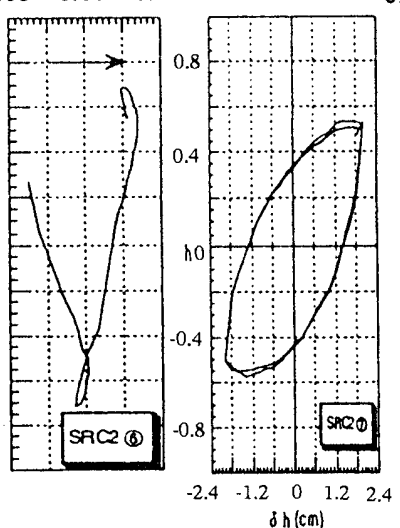

(d) $\mathrm{p}=-0.35($ (7) $)$

$\delta v(\mathrm{~cm})$

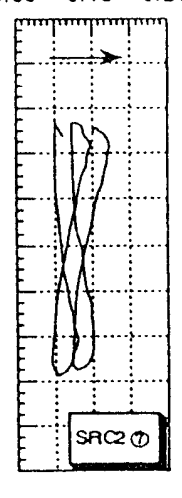

$\delta v(\mathrm{~cm})$
$0.06 \quad 0$

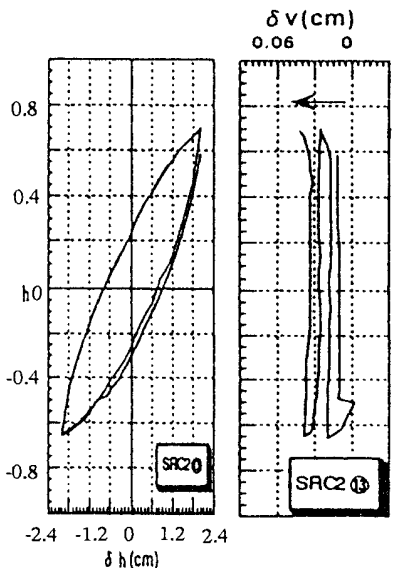

(f) $\mathrm{p}=0.05$ (13)

(e) $\mathrm{p}=0.08$ (12)

図14 SRC柱の履歴曲線 
（ ${ }_{\mathrm{w}} \mathrm{p}=0.43 \% 、 \mathrm{RC4} \sim \mathrm{RC6} 、$ せん断破壊タイプ）の計 8 体とした。試験 体RC4 RC6の終局せん断耐力の計算值は曲訬耐力を若干上回るが、 帯筋間隔が広いことを考慮してこれらの試験体の破壊形式をせん断 破壊とした。実験結果によると、これらの試験体には柱脚部のコン クリートにせん断クラックが入り、水平変位が制御不能となって耐 力が急激に低下する等せん断引張破壊の特徴が現われた。主筋及び 帯筋は、各々SD2950D10、D6であり、SRC試験体の内蔵鉄骨は $\mathrm{SS} 400$ のH-75 $\times 75 \times 3.2 \times 3.2 \mathrm{~mm}$ の組立H形鋼である。表 1 に各試験体 の実測寸法及びコンクリートの圧縮強度、表 2 に鉄筋及び鉄骨の機械 的性質を示す。

\section{2 実験方法}

収束限界軸力曲線を求めるため、軸力と繰返し水平力を受けるRC 柱とSRC柱の実験を行った。実験装置を図6に示す。試験体を口型フ レームに設置し、柱頭に30t油圧ジャッキによりRC柱では $\pm 10 \mathrm{~mm}$ 、 $\mathrm{SRC}$ 柱では土20mmの定変位振幅繰返し水平力（鉛直力であるが、表 現の都合上軸力に対して水平力と呼ぶ）を加え、さらに軸力を $100 t$ 油圧ジャッキにより軸力載荷用治具（ピン）を介して柱頭に加力し た。水平加力治具の両端はピン支持としており、軸力加力治具は 100t油圧ジャッキが移動できるように止端にスライド機構を挿入し た。

本実験では、2種類の載荷を行い収束限界軸力を得た。まず試験体 RC2、RC5、SRC1では、軸変位を一定に保ちながら繰返し水平力を 3サイクル加えた後、さらに逐次軸変位を増加して載荷した（加力方 法1:Test1）。このときの3サイクル目の変動軸力の最小值として逐次 収束限界軸力を得た。また試験体RC3、RC4では、より厳密な曲線を 得るために収束時軸変位 $\delta_{v}$ として一定值ではなく、前ステップの収 束限界軸力の下での繰返し載荷の結果得られた軸変位の履歷曲線を もとに、仮定された軸変位を与えながら定変位振幅絽返し水平力を 加えた（加力方法2、Test2)。これらによって得られた収束限界軸力 の妥当性について検討するため、試験体RC1、RC6、SRC2では一定 軸力下で繰返し水平力を加えて（加力方法 $3:$ Test3）、軸变形累積の 収束・発散挙動を調べた。表3に各試験体の破壊形式及び加力形式を まとめて示す。

柱頭の水平変位はスタンドに設置した変位計により測定され、柱 頭の軸変位は、柱頭及び柱脚間に設けられたスライド機構にとりつ けられた変位計により測定された。

\section{3 実験結果及び考察}

実験によって得られた結果を図7〜図14に示す。図6(a)、(b)は、加 力方法1により得られた試験体RC2、RC5の軸力p-軸変位 $\delta$ 、関係であ る。加力方法1、2いずれにおいても、2サイクル目における変動軸力

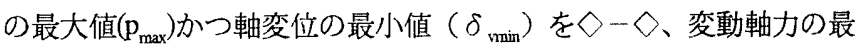
小值 $\left(\mathrm{p}_{\min }\right)$ かつ軸変位の最大值 $\left(\delta_{\text {max }}\right)$ を○ー○でそれぞれ示す。加 力方法1においても、軸変位一定の制御にも拘らず、軸変位の最大・ 最小に多少の違いは生じる。収束限界軸力曲線 (Critical Force for Conv.) は、これらの曲線の内側の実線で得られる。図8は、同じく 加力方法1により得られた試験体 SRC1の軸力 $\mathrm{p}$-軸変位 $\delta$ 、関係であ る。ここにRC柱のpは $\mathrm{F}_{\mathrm{c}} \cdot \mathrm{B} ・ \mathrm{D}$ で規準化された軸力であり $\mathrm{F}_{\mathrm{c}}$ はコン クリートの圧縮強度、B、Dは断面のせい及び幅である。SRC柱の軸 力pは（1）式で示される終局圧縮耐力"17で規準化されている。

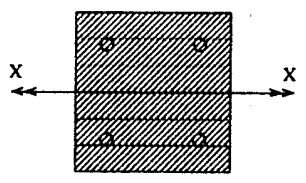

(a) モデルA (RC)

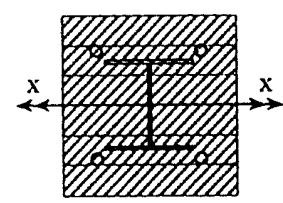

(c) モデルA (SRC)

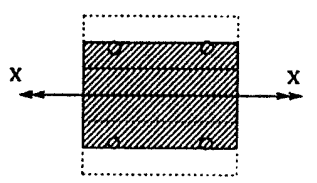

(b) モデルB (RC)

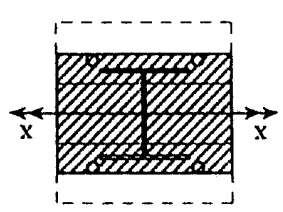

(d) モデルB (SRC)

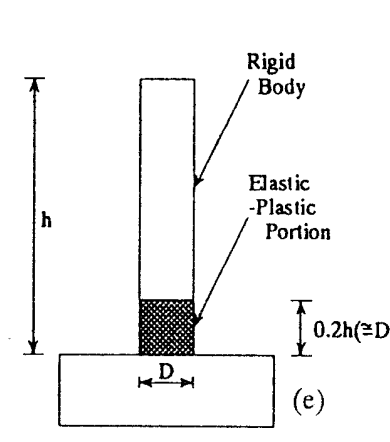

図15 解析モデル

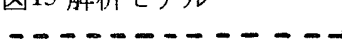

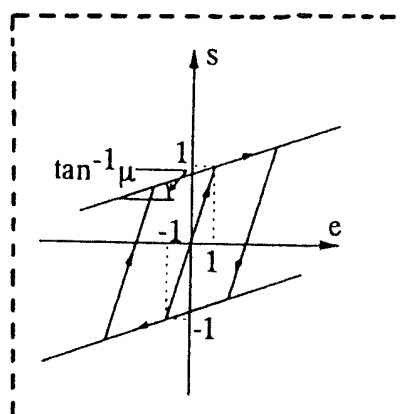

(a) 鉄筋及び鉄骨

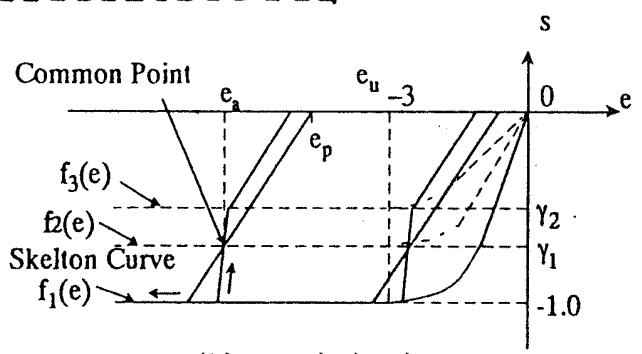

(b) コンクリート

図16 応力度一ひずみ度関係

$$
\begin{aligned}
& P_{u}={ }_{c} \gamma_{u} \cdot F_{c} B D+{ }_{s} a \cdot{ }_{s} \sigma_{y}+{ }_{r} a \cdot{ }_{r} \sigma_{y} \\
& { }_{c} \gamma_{u}=0.85-2.5 \cdot\left({ }_{s} a_{c} / B D\right)
\end{aligned}
$$

ここに $\mathrm{a}$ 及び $\mathrm{a}$ は各々鉄骨及び鉄筋の断面積、, $\sigma_{\mathrm{y}}$ 及び, $\sigma_{\mathrm{y}}$ は各々鉄骨 及び鉄筋の降伏応力度、 ${ }_{s} \mathrm{a}_{\mathrm{c}}$ は圧縮側フランジの断面積である。

図9(a)、(b)は加力方法2により得られた試験体RC3、RCAの軸力p一軸 変位 $\delta 、 ⿵^{\prime}$ 係である。図10(a)、(b)は加力方法3により得られた一定軸 力下でのRC柱の軸力p-軸変位 $\delta$ 、関係を図7及び図900-0と〉〉曲線の内側の曲線（図3の太い曲線に相当）として得られる収束 限界軸力曲線にそれぞれ重ね合わせたものである。図10では、軸力

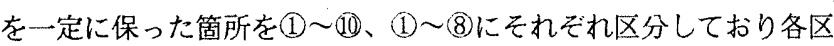
分の○-O、・-のは、各々変形累積が収束、発散したことを表わ す。図11(a)、(b)は、各々図10(a)中の(3)、(4)で示される $\mathrm{p}=-0.18 、-0.26$ の一定軸力下でのRC柱の水平力 $\mathrm{h}$-水平変位 $\delta_{\mathrm{h}}$ 関係及び水平力 $\mathrm{h}-$ 軸 変位 $\delta$ 、関係である。また図12(a)、(b)は図10(b)中の(4)、(5)で示される $\mathrm{p}=-0.33 、-0.410$ ときの結果である。ここにhは $\left\{\mathrm{a}_{\mathrm{f}} \sigma_{\mathrm{y}}\left(\mathrm{D}-2 \cdot \mathrm{d}_{\mathrm{c}}\right)+\right.$ $\left.0.12 \cdot \mathrm{B} \cdot \mathrm{D}^{2} \cdot \mathrm{F}_{\mathrm{c}}\right\} / \ell$ /規準化された水平力であり、 $\sigma_{y}$ は主筋の降 伏応力度、 $a_{1}$ は片側主筋の全断面積、 $\mathrm{d}_{\mathrm{c}}$ は主筋の中心からコンクリー

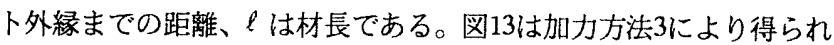


た一定軸力下でのSRC柱の軸力p - 軸変位 $\delta_{\mathrm{v}}$ 関係を図7の収束限界軸 力曲線にそれぞれ重ね合わせたものである。図14(a)〜(f)は各々図13 中の(3)、(4)、(6)、(7)、(12)、(13)で示される一定軸力 $\mathrm{p}=-0.17 、-0.23 、-$ $0.46 、-0.35 、 0.08 、 0.05$ の下でのSRC柱の水平力 $\mathrm{h}-$ 水平変位 $\delta_{\mathrm{h}}$ 関係 及び水平力 $\mathrm{h}$-軸変位 $\delta$ 、関係である。ここにhは（2）式の降伏水平 耐力 $\mathrm{H}_{\mathrm{y}}{ }^{17}$ により規準化された水平力である。

$H_{y}=\left\{\frac{{ }_{c} \gamma_{u}}{8} \cdot B D^{2} F_{c}+{ }_{s} Z_{p} \cdot{ }_{s} \sigma_{y}+\frac{{ }_{r} a}{2} \cdot{ }_{r} \sigma_{y} \cdot{ }_{r} d\right\} / \ell$

${ }_{\mathrm{s}} \mathrm{Z}_{\mathrm{p}}=$ 鉄骨の塑性断面係数、 $\mathrm{r}=$ 主筋間距離

収束限界軸力曲線の内側の軸力（図10(a)の(1)～(3)、(5)）の下では 損傷の累積はすぐに停止するが、曲線の外側の軸力（図10(a)の(4)、 (7)、(9)、(10)）の下では、曲げ破壊やせん断破壊による損傷は進行す る。図13中の(6)、(7)の履歴挙動を図14(c)、(d)に示しているが、軸力 の隔りが大きい(6)では軸変形の累積が大きい。図10(a)の(3)、(4)、図 10(b)の(4)、(5)および図13の9、(4)は各々軸変形が収束・発散するこ とを表しており、その収束限界は収束限界軸力曲線の極限点に対応 していることから、収束限界軸力曲線の高さが大きくなる程、柱の 累積損傷に対する抵抗が大きくなることが分る。また曲線の負勾配 が大きい図10(b)のせん断破壊タイプに比へて、負勾配が小さい図 10(a)の曲げ破壊夕イプの方が損傷の累積が小さいことから、収束限 界軸力曲線の負勾配が小さい程柱の累積損傷に対する抵抗が大きい ことが分る。なお図10中の加力方法1 (Test1)と加力方法2 (Test2)の結 果が示すように、加力方法の違いによる有意な差異は見られない。

以上の結果から、本実験で得られた収束限界軸力曲線により、 $\mathrm{RC}$ 柱やSRC柱の耐力低下の進行及び軸変位の累積の収束・発散現象が 予測できることが分かった。

\section{4. 軸力と綝返し水平力を受けるRC柱及びSRC柱の解析}

\section{1 解析方法}

図15はRC柱及びSRC柱の解析モデルである。柱断面は要素分割さ れており（図15(a)〜(d)）、全断面有効としたモデル（モデルA）及 び曲げによる縮破壊を想定して被りコンクリートを取り去ったモ デル (モデルB) をRC柱及びSRC柱に対して各々仮定した。モデル は図15(e)に示すように剛体と弾塑性体からなり、弾塑性体の長さは $0.2 \mathrm{~h}(\fallingdotseq \mathrm{D})$ とし、弾塑性体内の曲率は一定と仮定した。ここに 材長、 $\mathrm{D}=$ 断面せいである。

仮定した鉄筋、鉄骨及びコンクリートの応力度ーひずみ度関係を 各々図16(a)、(b)に示す。鉄骨、鉄筋及びコンクリートの応力度 $\mathrm{s及び}$ ひずみ度恪々の降伏応力度、压縮強度及びそれらに対応するひず みで規準化されている。ひずみ硬化係数 とした。コンクリートのs-丽係におけるスケルトン曲線を表わす関

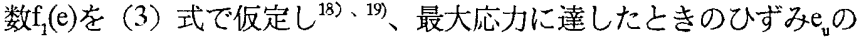
值は-3、 $\gamma_{1} 、 \gamma_{2}$ はそれぞれRC柱では0.7、0.5、SRC柱では内蔵鉄骨 によるコンクリートの充填性を考慮して0.4、0.2とした。

$$
\begin{aligned}
& f_{1}(e)=\frac{e}{1-\left(1+\frac{2}{e_{u}}\right) \cdot e+\left(\frac{e}{e_{u}}\right)^{2}} \quad \cdots \quad e \geq e_{u} . \\
& f_{1}(e)=-1 \text { - } e<e_{u}
\end{aligned}
$$

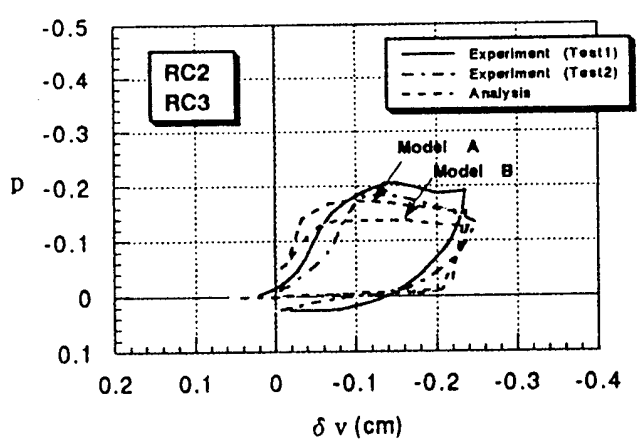

(a) 曲げ破壊タイプ

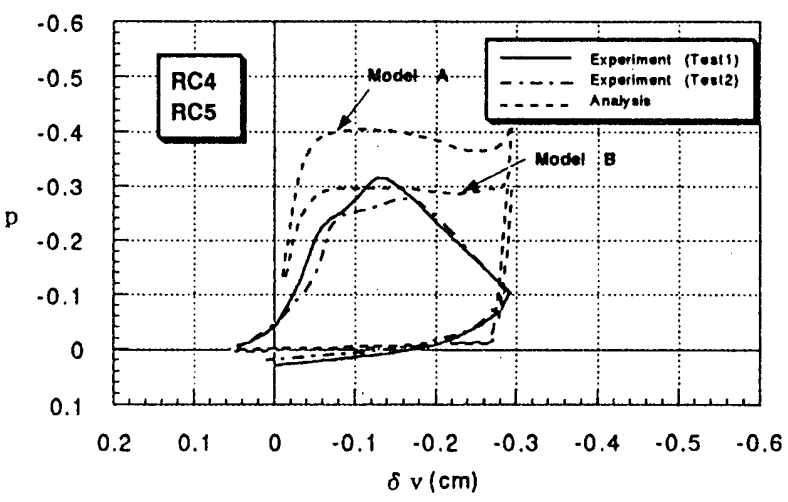

（b）せん断破壊タイプ

図17 実験及び解析から得られたRC柱の 収束限界軸力曲線の比較

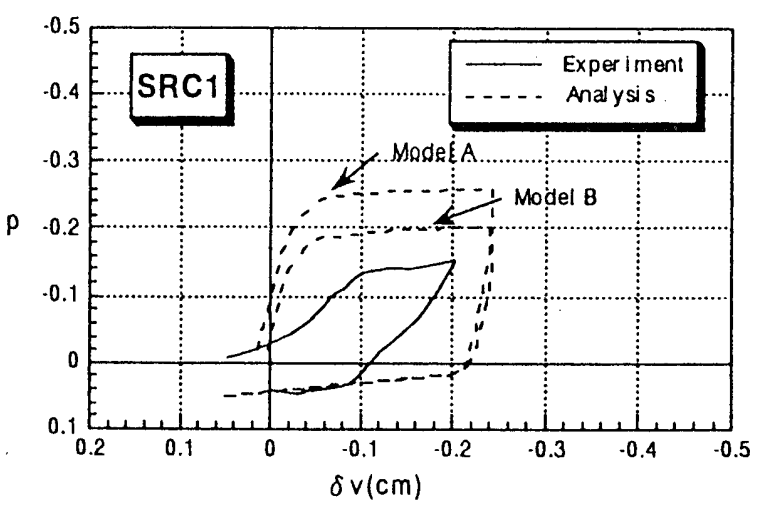

図18 実験及び解析から得られたSRC柱の 収束限界軸力曲線の比較

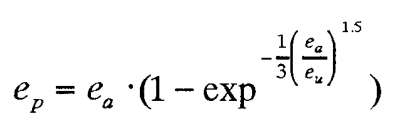

$f_{2}(e)=\gamma_{1} \cdot f_{1}(e) 、 f_{3}(e)=\gamma_{2} \cdot f_{1}(e) 、 \exp =2.7182 \cdots$ ここに $\mathrm{e}_{\mathrm{a}}=$ Common Pointのひずみ（図16(b)）、e $\mathrm{e}_{\mathrm{p}}=$ 塑性ひずみ

本計算では、加力方法 20 実験で収束限界軸力を求めたときと同様 に、収束時軸変位 $\delta_{\mathrm{v}}$ として一定值ではなく、前ステップの収束限界 軸力の下で繰返し水平力を加えたときの $\delta$ の履歴を基に定められた 值を仮定して弾塑性解析により収束限界軸力を求めた。計算では表 1、表2に示すパラメータを用い、コンクリートのヤング係数 $\mathrm{E}_{\mathrm{c}}=210 \mathrm{t}$ $\mathrm{cm}^{2} 、$ 鋼材のヤング係数 $\mathrm{E}_{\mathrm{s}}=2100 \mathrm{t} / \mathrm{cm}^{2}$ とした。ただしRC1〜 RC3 試験体 では、本実験に先立ち試験体に弾性範囲において軸方向加力を行 
なったところ、コンクリート充填不良のため軸方向剛性が理論值の 半分しかなかったため、コンクリート強度及びャング係数を上記の 半分とした。 $\mathrm{RC} 1 \sim \mathrm{RC}$ 試験体の施工不良は、他の試験体に比へて耐 力低下や剛性低下を大きく生じさせ、収束限界軸力曲線の最大値を 低くしたが、収束限界軸力曲線による累積損傷の予測に影響を与え るものではないと考えられる。コンクリート断面の分割数を6、鉄骨 断面モテルのウェブの分割数を10とし、フランジは分割していな い。

$\mathrm{RC}$ 柱の変位振幅 $\delta_{\mathrm{ha}}$ は実験之同様 $10 \mathrm{~mm} 、 \mathrm{SRC}$ 柱では $20 \mathrm{~mm}$ とし た。図15のモデルでは（4）式が成立するのでこの式を用いて、柱頭 水平変位 $\delta_{\mathrm{h}}$ から柱脚曲率 $\Phi$ を求め、変位增分法による弾塑性解析に より柱脚の曲げモーメント及び柱の水平力を得た。

$$
\frac{\Phi}{\Phi_{y}}=\frac{\delta_{h}}{\delta_{h y}}
$$

ここに $\Phi_{\mathrm{y}} 、 \delta_{\mathrm{hy}}$ は降伏時の $\Phi 、 \delta_{\mathrm{h}}$ である。

4.2 解析結果

解析により得られたRC柱及びSRC柱のモデルA並びにモデルBの収 束限界軸力曲線と実験から得られた収束限界軸力曲線との比較を 各々図17、18に示す。せん断破壊するケースに対しては、本来せん 断モデルを用いた解析により収束限界軸力曲線を求めなければなら ないが、繰返し力を受けたときの精度の良いせん断モテルが提案さ れていないことと、本ケースではせん断破壊夕イプのせん断耐力と 曲げ耐力が接近しているため曲げせん断破壊を考虑して、曲げ解析 を行なった。従って、試験体RC4、RC5のせん断破壊後の挙動に違い が見られるが、解析から得られた収束限界軸力曲線は実験結果と概 ね一致している。実験から得られた収束限界軸力曲線は累積損傷を 良好に予測することを3.で示したが、解析から得られた収束限界軸 力曲線は実験結果と対応しているため、解析から得られた収束限界 軸力曲線により柱の損傷予測が可能であると思われる。

\section{5. 結铪}

地震時の構造物の終局的な耐震性能を確保するためには、構造物 が十分な水平耐力を有するように設計しておくことは必要である が、さらに繰返し力が作用するときの耐力低下や変形累積等の累積 損傷に対して必要な抵抗性能を保持していることを保証することが 不可欠である。本研究では、構造物の自重を含めた鉛直力と地震力 等の水平力を同時に負担する役目を有する重要な構造材である柱 が、繰返し水平力を受けるときの性能を評価する方法を提示し、 $\mathrm{RC}$ 柱及びSRC柱の実験を行って、その評価方法の妥当性を検討した。 得られた結論は以下の通りである。

1)繰返し水平力を受け曲け破壊やせん断破壊を生じるRC柱やSRC柱 の損傷の累積に対する抵抗性能を評価する際、本研究で提示した収 束限界軸力曲線は有用である。

2)収束限界軸力曲線は履歴を描き、曲線の内側の軸力の下では損傷 の累積はすぐに停止するが、曲線の外側の軸力の下では曲げ破壊や せん断破壊による損傷は進行する。また曲線からの軸力の隔たりが 大きくなる程損傷の累積が増大する。

3)収束限界軸力曲線の極限点の高さが大きくなる程また負勾配の大 きさが小さくなる程、RC柱やSRC柱の累積損傷に対する抵抗が大き くなる。

4)解析により得られた収束限界軸力曲線は実験により得られた曲線
と概ね一致していることから、繰返し水平力を受ける柱の累積損傷 に対する抵抗性能を解析により評価できる。

\section{謝辞}

本研究を行うにあたり、平成7年度、8年度文部省科学研究費（基船研究 (C), (2)) の補助を受けた。また実験に際し、元技官の仮屋薗一樹氏、元 鹿児島大学生の日山正志氏や多くの研究室諸氏の協力を得た。

\section{参考文触}

1)近藤一夫、王学鋒、中倉健介、花井正実: 繰返し変動曲げを受ける銅柱の弾塑 性・前填举動、日本建築学会搆造系論文報告集、第434号、pp.59-74、1992.4

2)藤本盛久、羽倉弘人：繰返し荷重を受ける铁骨断面の弾塑性解析に関する研究 (第2 報)、日本建築学会論文報告集、第121号、pp.14-18、1966.3

3)Yamada, M.: Effect of Cyclic Loading on Buildings, Proceedings of the Intemational Conference on the Planning and Design of Tall Buildings, ASCE-IABSE, Lehigh University, 1972.8

4)内田保博 三谷勲 上遠野明夫：角形銅管柱の軸力比制限に関する実験的研究 日本建築学会構造系諭文報告集、第454号,pp.139-149、1993.12

5)坂本順: 繰返し外乱を受ける架構の局所累皘资形に関する考察、日本建筑学会諭 文報告集、第246号、pp.33-41、1976.8

6) Igarashi, S., Matui, C., Yoshimura, $\mathrm{K}$ and Matumura, $\mathrm{K}$ : Inelastic Behaviours of Structural Steel Sections under Altemative Loadings, Transactions of Architectural Institute of Japan, No. 169 , pp. 53-62, 1970.3

7)松井千秋、三谷勲：繰返し水平力を受け万高镸力銅骨組の弹塑性性状に関する研 究、日本建築学会論文報告集、第250号、pp.31-41、1976.12

8)加藤兔、秋山宏：鎆構造部材の耐力（その4）、日本建築学会諭文報告集、第151 号、pp.15-20、1968.9

9)中村桓善、上谷宏二：銷構造柱材に対する対称限界理諭（その1：一般的定式 化)、日本建築学会構造系論文報告集、第398号、pp.109-119、1989.4 10)上谷宏二、中村恒善：繰返し両振り曲げを受ける片持梁-柱の定常状態限界理 馀、その 1 : 基碳理諭及ひ離散化モデルを用いた数值解析法、日本建築学会構造 系諭文報告集、第438号、pp.105-115、1992.8

11)羽倉弘人：䆆返し荷重を受ける铁骨断面の弾塑性解析に関する研究（第3報）

（Beam Columnの濑增塑性限界荷重について）、日本建築学会論文報告集、第122 号、 pp.1-8. 1966.4

12)宇田川邦明、高梨晃一、田中尚：繰返し載荷を受けるH形銅はりの復元力特性 その1 · 定変位振幅繰り返し载荷時の塑性装形能力、日本建築学会諭文報告集、第 264号、pp.51-59、1978.2及びその2・ランタム変位履楚における耐力低下、第 265 号、pp.45-52、1978.3

13)松井千秋、津田恵吾、江冠華：繰返し曲计を受けるSRC柱材の安定限界軸力に 関する解析的研究、コンクリート工学論文集、第3巻1号、pp. 45-55、1992.1 14)平石久広、稻井栄一、薬研地彰: 繰返し載荷を受ける敘筋コンクリート造柱の 限界変形 鉄筋コンクリート造柱の曲け降伏後の限界変形に関する研究（その 3)、日本建筑学会構造系論文報告集、第454号、pp. 127-138、1993.12 15)衣笠秀行、野村設郎、太田雅昭、本間茂：RC曲け破壊部材の繰返し疲労損偒 特性、日本建築学会大会学術講演梗概集、pp. 253-254、C、1991.9 16)内田保博 小御門匡: 繰り返し外力を受けるトラス構造の耐力低下及び変形 累積举動に関する研究、日本建築学会構浩系諭文報告集、第454号、pp.161-170 1993.12

17) 日本建築学会 : 鉄骨鉄筋コンクリート構造計算規準・同解説、1987

18)Darwin, D. and Pecknold, D. A. W.: Inelastic Model for Cyclic Biaxial Loading of Reinforced Concrete, Univ. of Illinoi, Civ. Eng. Stud., SRS409, 1974.7

19)小坂義夫、谷川恭夫：高琅ひずみ領域におけるコンクリートの履歷特性、日 本建築学会大会学術講演梗概集、pp. 449-450、1978.9

20)古城康彦、内田保博：繰返し荷重を受けるRC柱及乙SRC柱の累皘損傷に関守る 研究、日本建筑学会大会学術講演梗概集、構造C-1、pp. 417-418、1994.9

21)内田保博 古城康彦、古里角栄、三谷勲、有馬冬樹: 繰り返し水平力を受ける 鉄筋コンクリート柱の累皘損偟の予測に関する実験的研究、日本建筑学会大会学 術講演梗概集、構造C-1、pp.313-314、1995.9

22)Uchida, Y:: Estimation of Cumulative Damage of Beam-Columns and Frames Subjected to Repeated Loading, Proceedings of $11 \mathrm{WCEE}$

CD-ROM, 1996.6

23)Uchida, Y., Kojo, Y. and Bochi, A: Prediction of Cumulative Damage in SRC BeamColumns, Intemational Conference on Composite Construction-Conventional and Innovative, pp.621-626, 1997.9

24)内田保博. 古城康彦、臼山正志、三谷勲、有馬冬樹：繰り返し水平力を受ける 鉄筋コンクリート柱の累皘損傷の予测に関する実験的研究(その2)、日本建築学会 大会学術講演梗概集、構造C-1、pp.217-218、1996.9

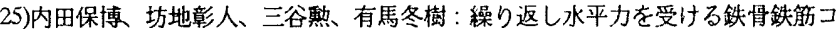
ンクリート柱の累皘損傷の予测に関する実験的研究、日本建築学会大会学術講演 梗概集、構造C-1、pp.983-984、1997.9

26)内田保博 古域康彦、臼山正志、三谷勲，有馬冬樹：繰り返し水平力を受ける 鉄筋コンクリート柱の累皘損傷の予測に関する実験的研究(その2)、日本建築学会 大会中国・九州支部研究報告、第10号、pp.493-496、1996.3

27)内田保博坊地彰人、三谷勲、有馬冬樹：繰り返し水平力を受け万鉄篔鉄筋コ ンクリート柱の累皘損鹪の予湘に関する実験的研究、日本建筑学会九州支部研究 報告、第36号、pp.493-496、1997.3

(1999年4月16日原稿受理，1999年8月16日採用決定) 